\title{
Effects of pumice mining on soil quality
}

\author{
A. Cruz-Ruíz ${ }^{1}$, E. Cruz-Ruíz ${ }^{1}$, R. Vaca ${ }^{2}$, P. Del Aguila ${ }^{2}$, and J. Lugo ${ }^{2}$ \\ ${ }^{1}$ Instituto de Ingeniería, Universidad Autónoma de Baja California, Mexicali, Baja California, Mexico \\ ${ }^{2}$ Facultad de Ciencias, Universidad Autónoma del Estado de México, Instituto Literario 100 Toluca, 50000 Mexico
}

Correspondence to: J. Lugo (jorgelug@gmail.com)

Received: 5 March 2015 - Published in Solid Earth Discuss.: 17 April 2015

Revised: 7 December 2015 - Accepted: 11 December 2015 - Published: 15 January 2016

\begin{abstract}
Mexico is the world's fourth most important maize producer; hence, there is a need to maintain soil quality for sustainable production in the upcoming years. Pumice mining is a superficial operation that modifies large areas in central Mexico. The main aim was to assess the present state of agricultural soils differing in elapsed time since pumice mining ( $0-15$ years) in a representative area of the Calimaya region in the State of Mexico. The study sites in 0, 1, 4, 10, and 15 year old reclaimed soils were compared with an adjacent undisturbed site. Our results indicate that gravimetric moisture content, water hold capacity, bulk density, available phosphorus, total nitrogen, soil organic carbon, microbial biomass carbon and phosphatase and urease activity were greatly impacted by disturbance. A general trend of recovery towards the undisturbed condition with reclamation age was found after disturbance, the recovery of soil total $\mathrm{N}$ being faster than soil organic $\mathrm{C}$. The soil quality indicators were selected using principal component analysis (PCA), correlations and multiple linear regressions. The first three components gathered explain $76.4 \%$ of the total variability. The obtained results revealed that the most appropriate indicators to diagnose the quality of the soils were urease, available phosphorus and bulk density and minor total nitrogen. According to linear score analysis and the additive index, the soils showed a recuperation starting from 4 years of pumice extraction.
\end{abstract}

\section{Introduction}

Land degradation refers to a process induced by human activities that cause the decrease in biological productivity or biodiversity, as well as the current capacity and/or potential to sustain human life (Oldeman, 1998). Land degradation and desertification affect many regions of the world (Cerdà et al., 1999; Bai et al., 2013; Izzo et al., 2013; Wang et al., 2013; Yan and Cai, 2015) and there is a need to restore those areas affected by land degradation processes (Guénon et al., 2013; Özcan et al., 2013; Kröpfl et al., 2013; Li et al., 2013; Tejada and Benitez, 2014; Zucca et al., 2015). Soil degradation can also interfere with normal nutrient cycling and habitat quality, as well as hamper the latter's natural buffering ability (Keesstra et al., 2012; Berendse et al., 2015; Brevik et al., 2015). There are examples of studies in opencast coal mines, magnesite mines and limestone mines (Raizada and Juyal, 2012; Haigh et al., 2015; Martín-Moreno et al., 2013; Milder et al., 2013; Pallavicini et al., 2015; Mukhopady and Maiti, 2014; Wick et al., 2014), whilst there are few studies on opencast pumicite mines.

Open pit mining has great economic importance in Mexico; therefore, taking the volume of production of nonmetallic minerals as an indicator, the State of Mexico is the largest producer of non-metallic minerals mainly extracted, i.e., sand and gravel (Jimenez et al., 2006). In the agricultural area of the Municipality of Calimaya highlands in the State of Mexico, opencast mining is carried out. After extractive operations in the pumice areas, agricultural use is continued, although productivity declines while the landscape and soil characteristics are substantially altered. These facts show the need for suitable correction management actions to accelerate the succession process and return of the degraded area to an environmentally acceptable and productive condition (Rogowski and Weinrich, 1987). Pumice is a volcanic rock with trapped gas bubbles formed during volcanic eruptions (Whitham and Sparks, 1986); it is made up of $\mathrm{Si}, \mathrm{Al}, \mathrm{K}, \mathrm{Na}$, and $\mathrm{Fe}$ oxides, with a small percentage of $\mathrm{Ca}, \mathrm{Mg}, \mathrm{Mn}$, and Ti oxides (Liguori et al., 1984). 
The main causes of land degradation during mining operations are (1) removal of vegetation cover and topsoil, (2) excavation and dumping of overburden, (3) changes in the landscape (Mukhopadhyay et al., 2013), (4) disruption of surface and subsurface hydrologic regimes, (5) transformation of fertile cultivated land into wasteland and, in some cases, (6) serious environmental pollution and ecological degradation, which can lead to loss of biodiversity (Keskin and Makineci, 2009). Soil in mined sites is replaced by overburden, which differs substantially from developed soils (Huggett, 1998; Keskin and Makineci, 2009), with adverse properties such as severe depletion of organic matter, erosion risk, toxicity, and nutrient deficiency, which commonly reduce productivity in post-mining landscapes (Sourkova et al., 2005).

In a post-mining landscape, the regeneration of the uppermost soil layer, organ-mineral horizon, and soil biota is necessary, which transforms organic matter (Frouz et al., 2001). The accumulation of organic matter (OM) is critical because it results in positive changes in physical and chemical soil properties, such as water holding and sorption capacities, nutrient content and availability, soil bulk density, and buffering capacity, and increases microbial biomass and extractable carbon, microbial community structure and biodiversity. Moreover, OM is an energy source for the soil microorganisms, which drives decomposition and mineralization of plant residues, thereby releasing nutrients (Sourkova et al., 2005; Laudicina et al., 2015)

Soil quality included physical, chemical and biological properties, as well as soil processes and their interactions. The selection of some properties to assess soil quality is an effective way. Some authors have used independent indicators, while others preferred their combinations into models or expressions in which various properties are involved; these expressions are called indices (Graham and Haynes, 2004; Hussain et al., 2008; Wick et al., 2014; Zornoza et al., 2015). The establishment of multiparametric indices has been used as an adequate tool for integrating greater information of soil quality. It provides a more holistic measurement of soil quality (Brevik et al., 2015; Zhang et al., 2015). Several studies have generated indices from a data set using physical, chemical and biological indicators. Organic carbon, microbial biomass and enzyme activity have been widely used to assess impact of change in land use and reclaimed soils (Chodak and Niklinska, 2010).

Enzyme activity measurement is widely used to examine nutrient cycling processes in soil (Nannipieri et al., 1990; Tabatabai and Dick, 2002). Moreover, enzyme activities can provide indications of quantitative changes in soil organic matter and are usually related to the presence of viable microorganisms and their oxidative activities (Gianfreda et al., 2005), which could be sensitive indicators of the effect of land degradation on soil microbial activity. Soil hydrolyses measurements provide an early indication of changes in soil fertility, since they are related to the mineralization of important elements such as nitrogen, phosphorus and carbon, and may provide some insight into the metabolic capacity of the soil (Shaw and Burns, 2006; García-Orenes et al., 2010). Urease plays an important role in soil nitrogen cycle because it can hydrolyze urea, an important fertilizer in agricultural systems to ammoniacal nitrogen (Sinsabaugh et al., 2000; Caldwell, 2005). Catalase has a great effect on changing soil redox, chemical properties of soil solution, and accelerating transformation of organic matter (Wang et al., 2012). The metabolic quotient estimates the activity and efficiency of decomposition (or $\mathrm{C}$ use) by soil microbes (Anderson and Domsch, 1990) and is a suitable indicator to provide evidence of soil perturbation (Zornoza et al., 2015).

Little information exists about how mining affects soil in cropland regions of the world and especially those of the central highlands of Mexico. The present work aimed to assess the changes produced in the agricultural soils differing in elapsed time since pumice mining ( $0-15$ years). With the information from this study, we examine valuable indicators of surface mine reclamation progress in opencast mines.

\section{Materials and methods}

\subsection{Study site}

This study was conducted in Calimaya, State of Mexico (central Mexico; $\left.19^{\circ} 13^{\prime} 25^{\prime \prime} \mathrm{N}, 99^{\circ} 44^{\prime} 02^{\prime \prime} \mathrm{W}\right)$, where the mean annual temperature is $14^{\circ} \mathrm{C}$ and the annual rainfall is $800 \mathrm{~mm}$ (GEM, 2012). The dominant climate is subhumid with summer rains. Dominant soils are Andosols (IUSS Working Group WRB, 2014). The main type of land use in the region is cropland based on maize. Cultivation techniques consist of monoculture, crop residue removal, and the use of $\mathrm{N}$ fertilizer, herbicides and pesticides. The change in use from agricultural land to urban land caused a decline in cultivated land from 7508 to 5350 ha between 2010 and 2011 (GEM, 2012). Following standard practice on surface mining sites, the topsoil was stripped and stockpiled until mining operations were completed; stored soil was then spread on top of overburden.

\subsection{Sampling process}

In February 2011, five mine sites, differing in elapsed time since reclamation ( $0-15$ years), of opencast pumice mine soils in central Mexico were chosen on the basis of similarity of aspect as well as proximity to one another and an adjacent undisturbed site, for comparison, located about 2800-2950 m above sea level. Treatments were considered as $S_{0}, S_{1}, S_{4}$, $S_{10}$ and $S_{15}$ with regard to the time since pumice mining took place: 2 months, 1 year, 4 years, 10 years and 15 years, respectively. We used a control treatment that was never mined, considered as undisturbed soil $(S)$. Pumice extraction can be 1 to several meters deep. In all areas immediately after the removal maize crop was continued under seasonal conditions. 
The slopes of the sampling sites ranged from 25 to $30 \%$. The pumice layer was located $30-180 \mathrm{~cm}$ deep.

Surface mining is one of the most complete forms of human-caused habitat alteration and degradation. In this case, mining eliminates vegetation, removes topsoil $(30 \mathrm{~cm})$ and overburden by excavation, and changes topography and geological structures permanently. The reclamation process involved the return of topsoil after mining exploitation. These new altered soils are called reclaimed mine soils, which have a different year of agriculture use.

These sites had been continuously cultivated since reclamation of mine spoils; surface soil samples $(0-15 \mathrm{~cm}$ depth) were taken in February (during the dry season), June (onset of the rainy season), and March 2012 (during the dry season), and stored at $4{ }^{\circ} \mathrm{C}$ for biochemical analyses. Soil samples were dried at room temperature and, afterwards, they were passed through a $2 \mathrm{~mm}$ mesh sieve.

Sampling sites were selected considering the extraction pumice times; the distance between them was $450 \mathrm{~m}$ and the area 3 ha. The soil sampled from each field was pooled separately. By systematic sampling at each site, a composite sample from 30 subsamples was collected from six treatments $(S$, $S_{0}, S_{1}, S_{4}, S_{10}$ and $S_{15}$ ).

\subsection{Laboratory analysis}

The following parameters were analyzed: gravimetric moisture content (GMC), which was measured gravimetrically, water holding capacity (WHC) according to Alef and Nannipieri (1995), and soil bulk density (BD) as described by Domínguez and Aguilera (1987). The soil $\mathrm{pH}$ and electrical conductivity (CE) were determined in soil/water $(1: 2.5$ $w / v$ ) (Thomas, 1996). Content of soil organic carbon (SOC) was determined by the Walkley-Black method (Nelson and Sommers, 1996), total nitrogen (TN) with Kjeldahl digestion (Bremner, 1996), and available phosphorus by the Olsen method.

Microbial biomass carbon (MBC) of soil samples was estimated by the chloroform fumigation and extraction method (Vance et al., 1987). Basal respiration (BR) was estimated by quantifying the carbon dioxide $\left(\mathrm{CO}_{2}\right)$ released by microbial respiration in 33 days of incubation at $25^{\circ} \mathrm{C}$ adjusted to $40 \%$ water holding capacity (WHC). For this purpose, $25 \mathrm{~g}$ soil was filled into flasks, together with small flasks containing $10 \mathrm{~mL}$ of $0.2 \mathrm{~mol} \mathrm{~L}^{-1} \mathrm{NaOH}$, to capture the released $\mathrm{CO}_{2}$, and hermetically sealed. $\mathrm{CO}_{2}$ was determined by titration with $0.2 \mathrm{~mol} \mathrm{~L}^{-1} \mathrm{HCl}$, after precipitation of the barium carbonate resulting from the addition of $\mathrm{BaCl}_{2}$ to the $\mathrm{NaOH}$ solution, using phenolphthalein diluted in $100 \mathrm{~mL}$ ethanol $(60 \%, v / v)$ as an indicator (Alef and Nannipieri, 1995).

Catalase activity was measured by titrating the residual $\mathrm{H}_{2} \mathrm{O}_{2}$ added to the soil and not degraded by catalase with $\mathrm{KMnO}_{4}$ (Johnson and Temple, 1964). Acid phosphatase activity was measured by spectrophotometry $(400 \mathrm{~nm})$ of $p$ nitrophenol released from $1.0 \mathrm{~g}$ soil after a $60 \mathrm{~min}$ incuba- tion at $37^{\circ} \mathrm{C}$ with a $0.025 \mathrm{~mol} \mathrm{~L}^{-1} p$-nitrophenyl phosphate substrate, in $4 \mathrm{~mL}$ of $0.17 \mathrm{~mol} \mathrm{~L}^{-1}$ MUB (universal buffer), at pH 5 (Tabatabai and Bremmer, 1969). Urease activity was determined as the amount of $\mathrm{NH}_{4}^{+}$released from $5.0 \mathrm{~g}$ soil after a 120 min incubation with a substrate of $0.2 \mathrm{~mol} \mathrm{~L}^{-1}$ urea at $37^{\circ} \mathrm{C}, 4.5 \mathrm{~mL}$ of THAM (Tris buffer) (Alef and Nannipieri, 1995). The metabolic quotient $\left(q \mathrm{CO}_{2}\right)$ was calculated as the ratio of basal respiration to MBC (Anderson and Domsch, 1990).

\subsection{Statistical analysis}

An analysis of variance (ANOVA) and Tukey test at $95 \%$ confidence level were performed to detect significant differences in soil samples with different years of extraction of pumice. Only those soil properties that showed significant differences were selected to represent a minimum data set (MDS). Significant variables were chosen for the principle component analysis (PCA); the PCs with eigenvalues $>1$ and those that explained at least $5 \%$ of the variation in the data were examined; the values of the variables were standardized by subtracting their means and dividing by their standard deviations. When more than one factor was retained under a single PC, multivariate correlation coefficients was employed to determine whether the variables could be considered redundant and therefore eliminated from the MDS. Well-correlated variables were considered redundant, and only one was considered for the MDS. The rest were eliminated from the data set. When all the indicators that were retained in the MDS were regressed as independent variables, with data on time extraction pumice as dependent variables, the coefficient of determination $\left(R^{2}\right)$ with $S, S_{0}, S_{1}, S_{4}, S_{10}$ and $S_{15}$ was calculated.

After determining the variables for the MDS, every observation of each MDS indicator was transformed for inclusion in the soil quality index (SQI) methods by linear scoring. Indicators were ranked in ascending or descending order depending on whether a higher value was considered "good" or "bad" in terms of soil function. For "more is better" indicators, each observation was divided by the highest observed value such that the highest observed value received a score of 1. For "less is better" indicators, the lowest observed value (in the numerator) was divided by each observation (in the denominator) such that the lowest observed value received a score of 1 .

The additive index was a summation of the scores from MDS indicators. From these summed scores, the additive SQI treatment means, ANOVA and Tukey test were calculated (Andrew et al., 2002). 
Table 1. Properties of soil samples with different years of extraction of pumice.

\begin{tabular}{|c|c|c|c|c|c|c|}
\hline & $S$ & $S_{0}$ & $S_{1}$ & $S_{4}$ & $S_{10}$ & $S_{15}$ \\
\hline $\mathrm{GMC}\left(\mathrm{g} \times 100 \mathrm{~g}^{-1}\right)$ & $2.81+0.17^{\mathrm{A}}$ & $1.99+0.16^{\mathrm{BC}}$ & $2.16+0.15^{\mathrm{BC}}$ & $2.29+0.16^{\mathrm{AB}}$ & $1.55+0.08^{\mathrm{C}}$ & $2.23+0.02^{\mathrm{AB}}$ \\
\hline WHC $\left(\mathrm{g} \times 100 \mathrm{~g}^{-1}\right)$ & $35.78+1.33^{\mathrm{A}}$ & $30.33+0.33^{\mathrm{B}}$ & $31.22+0.64^{\mathrm{B}}$ & $31.33+0.93^{\mathrm{B}}$ & $28.00+0.5^{\mathrm{B}}$ & $31.22+0.74^{\mathrm{B}}$ \\
\hline pH 1:2.5 (soil : $\left.\mathrm{H}_{2} \mathrm{O}\right)$ & $5.3+0.2^{\mathrm{A}}$ & $5.8+0.1^{\mathrm{A}}$ & $5.9+0.2^{\mathrm{A}}$ & $5.9+0.2^{\mathrm{A}}$ & $5.3+0.1^{\mathrm{A}}$ & $5.5+0.1^{\mathrm{A}}$ \\
\hline $\mathrm{EC}\left(\mathrm{d} S \mathrm{~m}^{-1}\right)$ & $0.153+0.021^{\mathrm{A}}$ & $0.154+0.007^{\mathrm{A}}$ & $0.201+0.039^{\mathrm{A}}$ & $0.199+0.035^{\mathrm{A}}$ & $0.274+.054^{\mathrm{A}}$ & $0.283+0.047^{\mathrm{A}}$ \\
\hline $\mathrm{BD}\left(\mathrm{g} \mathrm{cm}^{-3}\right)$ & $1.05+0.02^{\mathrm{C}}$ & $1.16+0.01^{\mathrm{B}}$ & $1.16+0.01^{\mathrm{B}}$ & $1.20+0.01^{\mathrm{AB}}$ & $1.25+0.02^{\mathrm{A}}$ & $1.15+0.02^{\mathrm{B}}$ \\
\hline $\mathrm{P}\left(\mathrm{mg} \mathrm{kg}^{-1}\right)$ & $16.40+0.17^{\mathrm{C}}$ & $16.57+0.13^{\mathrm{C}}$ & $17.98+0.21^{\mathrm{C}}$ & $17.47+0.16^{\mathrm{C}}$ & $22.01+0.47^{\mathrm{A}}$ & $19.45+0.28^{\mathrm{B}}$ \\
\hline $\mathrm{TN}\left(\mathrm{g} \times 100 \mathrm{~g}^{-1}\right)$ & $0.247+0.020^{\mathrm{A}}$ & $0.096+0.007^{\mathrm{C}}$ & $0.110+0.001^{\mathrm{C}}$ & $0.133+0.010^{\mathrm{BC}}$ & $0.176+0.006^{\mathrm{B}}$ & $0.130+0.010^{\mathrm{C}}$ \\
\hline SOC & $2.56+0.07^{\mathrm{A}}$ & $1.07+0.09^{\mathrm{C}}$ & $1.13+0.08^{\mathrm{C}}$ & $1.15+0.12^{B C}$ & $1.54+0.05^{\mathrm{B}}$ & $1.17+0.13^{\mathrm{BC}}$ \\
\hline $\mathrm{C} / \mathrm{N}$ & $10.36^{\mathrm{A}}$ & $11.15^{\mathrm{A}}$ & $10.27^{\mathrm{A}}$ & $8.65^{\mathrm{A}}$ & $8.75^{\mathrm{A}}$ & $9.00^{\mathrm{A}}$ \\
\hline $\mathrm{MBC}$ & $321.9+35.8^{\mathrm{A}}$ & $175.5+57.2^{\mathrm{B}}$ & $200.4+22.0^{\mathrm{AB}}$ & $220.6+24.9^{\mathrm{AB}}$ & $223.9+34.2^{\mathrm{AB}}$ & $245.0+39.4^{\mathrm{AB}}$ \\
\hline $\begin{array}{l}\text { Phosphatase } \\
\text { (mmoles: } \mathrm{PNP} \mathrm{g}^{-1} \mathrm{~h}^{-1} \text { ) } \\
\text { Urease }\end{array}$ & $2.84+0.22^{\mathrm{A}}$ & $2.07+0.20^{\mathrm{AB}}$ & $2.00+0.18^{\mathrm{AB}}$ & $1.74+0.27^{\mathrm{B}}$ & $2.59+0.24^{\mathrm{AB}}$ & $2.71+0.21^{\mathrm{A}}$ \\
\hline $\begin{array}{l}\left(\text { mmoles } \mathrm{N}-\mathrm{NH}_{4}^{+} \mathrm{g}^{-1} \mathrm{~h}^{-1}\right) \\
\text { Catalase }\end{array}$ & $11.78+1.22^{\mathrm{A}}$ & $7.78+0.95^{\mathrm{B}}$ & $10.11+0.87^{\mathrm{AB}}$ & $9.67+0.99^{\mathrm{AB}}$ & $8.33+1.11^{\mathrm{AB}}$ & $12.00+0.71^{\mathrm{A}}$ \\
\hline $\begin{array}{l}\left(\text { mmoles } \mathrm{H}_{2} \mathrm{O}_{2} \text { consumed } \mathrm{g}^{-1} \mathrm{~h}^{-1}\right) \\
\mathrm{CO}_{2}\end{array}$ & $0.241+0.033^{\mathrm{A}}$ & $0.159+0.026^{\mathrm{A}}$ & $0.178+0.031^{\mathrm{A}}$ & $0.194+0.026^{\mathrm{A}}$ & $0.219+0.029^{\mathrm{A}}$ & $0.240+0.029^{\mathrm{A}}$ \\
\hline$\left(\mathrm{mg} \mathrm{C}-\mathrm{CO}_{2} \mathrm{~kg}^{-1} \mathrm{~s}^{-1}\right)$ & $1826.9+218.2^{\mathrm{A}}$ & $1451.2+156.1^{\mathrm{A}}$ & $1505.0+161.1^{\mathrm{A}}$ & $1505.1+162.6^{\mathrm{A}}$ & $1639+186.4^{\mathrm{A}}$ & $1709.5+205.0^{\mathrm{A}}$ \\
\hline$q \mathrm{CO}_{2}$ & $2.12+0.36^{\mathrm{A}}$ & $3.38+0.41^{\mathrm{A}}$ & $2.68+0.29^{\mathrm{A}}$ & $2.48+0.23^{\mathrm{A}}$ & $3.24+0.44^{\mathrm{A}}$ & $2.70+0.28^{\mathrm{A}}$ \\
\hline
\end{tabular}

GMC: Gravimetric moisture content; WHC: water holding capacity; EC: electrical conductivity; BD: bulk density; P: available phosphorus; TN: total nitrogen; SOC: soil organic carbon; MBC: microbial biomass $\mathrm{C} ; \mathrm{CO}_{2}$ : respiratory activity; $q \mathrm{CO}_{2}$ : metabolic quotient; $S$ : undisturbed soils; $S_{0}$ : recently mined; $S_{1}: 1$ year old mined; $S_{4}: 4$ year old mined; $S_{10}: 10$ year old mined; $S_{15}: 15$ year old mined. Mean \pm error standard. Different letters in the same column denote significant differences $(p<0.05)$.

Table 2. Principle component analysis (PCA) of soil quality indicators of soil samples with different years of extraction of pumice.

\begin{tabular}{lrrr}
\hline & PC1 & PC2 & PC3 \\
\hline Eigenvalue & 3.6 & 1.7 & 1.6 \\
\% of variance & 39.8 & 18.8 & 17.9 \\
Cumulative \% & 39.8 & 58.6 & 76.4 \\
MBC & 0.381 & -0.175 & 0.342 \\
SOC & 0.403 & -0.270 & 0.104 \\
GMC & 0.468 & 0.037 & -0.060 \\
BD & -0.228 & 0.084 & 0.560 \\
Phosphatase & 0.212 & 0.482 & 0.273 \\
P & -0.236 & -0.134 & 0.570 \\
WHC & 0.376 & 0.412 & -0.172 \\
TN & 0.420 & -0.161 & 0.321 \\
Urease & 0.066 & -0.665 & -0.164 \\
\hline
\end{tabular}

MBC: microbial biomass C; SOC: soil organic carbon; GMC: gravimetric moisture content; $\mathrm{BD}$ : bulk density; $\mathrm{P}$ : available phosphorus; WHC: water holding capacity; TN: total nitrogen.

\section{Results}

\subsection{Basic soil properties and biological parameters}

Electrical conductivity, $\mathrm{pH}$, ratio $\mathrm{C} / \mathrm{N}$, catalase, $\mathrm{CO}_{2}$ and $q \mathrm{CO}_{2}$ did not significantly differ between the soil samples with different years of extraction of pumice (Table 1). Nevertheless, the respiration rate was higher in undisturbed soils than in soil post mining. On the other hand, the $q \mathrm{CO}_{2}$ values were higher in mine soils compared to the undisturbed soils (Table 1).

Mean of gravimetric moisture content (GMC) and water hold capacity (WHC) showed the next data respectively; $S_{10}$ showed the significant lowest value for GMC, without significant differences with $S_{0}$ and $S_{1}$. The highest values for GMC were shown by $S, S_{4}$ and $S_{15}$, with no significant differences among them. WHC showed no significant differences among mined soils, only the $S$ soil being significantly higher than the rest. No significant differences among treatments were observed in $\mathrm{pH}$ and EC. BD showed the significantly lowest value for $S$, with significant increments in mined soils. The highest value was observed in $S_{10}$ and $S_{4}$. Available P followed the increasing trend $S=S_{0}=S_{1}=S_{4}<S_{15}<S_{10}$. SOC and TN showed a similar trend. There were no significant differences among $S_{0}, S_{1}, S_{4}$ and $S_{15}$, which showed the lowest values. The highest values were observed in the $S$ treatment. MBC showed the highest value in $S$, which was only significantly different than S0, which showed the lowest value; in fact, MBC significantly decreased $\sim 50 \%$ in $S_{0}$ soil with regards to $S$. As a general pattern, enzyme activities increased with the time since the pumice mining was carried out, with $S$ soil showing the highest activities. The phosphatase showed the lowest significant activity in $S_{4}$, with no significant differences with $S_{0}, S_{1}$ and $S_{10} . S_{15}$ and $S$ showed the highest values, without significant differences between these two soils. Urease activity showed the highest values in $S$ and $S_{10}$, which were only significantly different to $S_{0}$. The catalase activity, $\mathrm{CO}_{2}$ and the $q \mathrm{CO}_{2}$ showed no significant differences among treatments (Table 1 ).

\subsection{Soil quality indicators}

Soil responses to different elapsed times since reclamation are presented in Table 1. A significant effect of time pumice extraction was observed on nine variables: GMC, WHC, 
Table 3. Correlation matrix for highly weighted variables under PCs with high factor loading.

\begin{tabular}{lrrr}
\hline Variables & Soil organic carbon & GMC & Total nitrogen \\
\hline PC1 variables & & & \\
Pearson's correlations & 1.000 & $0.487^{* *}$ & $0.765^{* *}$ \\
Soil organic carbon & $0.487^{* *}$ & 1.000 & $0.596^{* *}$ \\
GMC & $0.765^{* *}$ & $0.596^{* *}$ & 1.000 \\
Total nitrogen & 2.252 & 2.083 & 2.361 \\
Correlation sums & & & \\
\hline PC2 variables & Urease & & \\
Urease & 1.000 & & \\
& & & \\
\hline PC3 variables & Bulk density & Available P & \\
Bulk density & 1.000 & $0.475^{* *}$ & \\
Available P & $0.475^{* *}$ & 1.000 & \\
\hline
\end{tabular}

GMC: gravimetric moisture content. ${ }^{* *} p<0.01$

Table 4. Coefficient of determination and multiple regressions of the minimum data set (MDS) variables.

\begin{tabular}{cclc}
\hline & $R^{2}$ & Multiple regressions & $p$ value \\
\hline$S$ & 0.759 & $\mathrm{TN}=-1.08-0.01$ urease $+0.75 \mathrm{BD}+0.04 \mathrm{P}$ & $<0.10$ \\
& 0.830 & urease $=-66-25.6 \mathrm{TN}-22.6 \mathrm{BD}+6.6 \mathrm{P}$ & $<0.05$ \\
& 0.846 & $P=9.0+1.8 \mathrm{TN}+5.4 \mathrm{BD}+0.11$ urease & $<0.05$ \\
& 0.780 & $\mathrm{BD}=0.08+0.35 \mathrm{TN}+0.06 \mathrm{P}-0.004$ urease & $<0.05$ \\
\hline$S_{0}$ & 0.930 & urease $=-68.4-20.6 \mathrm{BD}+6.1 \mathrm{P}-18.4 \mathrm{TN}$ & $<0.01$ \\
& 0.934 & $P=17.6-1.8 \mathrm{BD}+0.11$ urease $+2.7 \mathrm{TN}$ & $<0.01$ \\
& 0.819 & $\mathrm{BD}=1.6-0.03 \mathrm{P}-0.005$ urease $-0.06 \mathrm{TN}$ & $<0.05$ \\
\hline$S_{1}$ & 0.873 & urease $=102.8-62.5 \mathrm{BD}-0.53 \mathrm{P}-100.8 \mathrm{TN}$ & $<0.05$ \\
& 0.883 & $\mathrm{BD}=1.68-0.01$ urease $-0.015 \mathrm{P}-1.26 \mathrm{TN}$ & $<0.01$ \\
\hline \multirow{2}{*}{$S_{10}$} & 0.893 & urease $=-76.8+32.3 \mathrm{BD}+1.7 \mathrm{P}+40.3 \mathrm{TN}$ & $<0.01$ \\
& 0.837 & $\mathrm{P}=40.4-14.3 \mathrm{BD}+0.47$ urease $-25.9 \mathrm{TN}$ & $<0.05$ \\
& 0.753 & $\mathrm{BD}=1.88-0.03 \mathrm{P}+0.02$ urease $-0.36 \mathrm{TN}$ & $<0.10$ \\
\hline \multirow{2}{*}{$S_{15}$} & 0.901 & $\mathrm{TN}=-0.26+4.8 X 10^{-5}$ urease $+0.40 \mathrm{BD}-0.004 \mathrm{P}$ & $<0.01$ \\
& 0.723 & $\mathrm{P}=29.6-0.25$ urease $-5.31 \mathrm{BD}-8.25 \mathrm{TN}$ & $<0.05$ \\
& 0.910 & $\mathrm{BD}=1.18-0.005$ urease $-0.011 \mathrm{P}+1.85 \mathrm{TN}$ & $<0.01$ \\
\hline
\end{tabular}

TN: total nitrogen; P: available phosphorus; BD: bulk density; S: undisturbed soils; $S_{0}$ : recently mined; $S_{1}$ : 1 year old mined; $S_{4}: 4$ year old mined; $S_{10}: 10$ year old mined; $S_{15}: 15$ year old mined.

CBM, SOC, BD, phosphatase, $\mathrm{P}, \mathrm{TN}$ and urease $(p<0.05)$. These parameters were retained for PCA.

In the PCA of nine variables, the first three PCs had eigenvalue $>1$ and explained $76.4 \%$ of the variance in the data (Table 2). Highly weighted variables under PC1 included GMC, SOC, and TN. A correlation matrix for the highly weighted variables under different PCs was run separately (Table 3). It was assumed that the variables having the highest correlation sum best represented the group. Among the three variables in PC1, TN was chosen for the MDS because of its highest correlation sum. The soil organic carbon had the second lowest correlation sum, but was highly correlated with TN $(r=0.77)$, and hence it was dropped. The variable with lowest correlation sum was GMC and it was retained for MDS. Under PC2 and PC3 urease, bulk density and available phosphorus were highly weighted; the three variables were retained in MDS because of their relative importance in volcanic soils.

Multiple regressions (Table 4) revealed that urease, available phosphorus and bulk density significantly influenced all time extraction goals $(p<0.05)$, while the effect of total nitrogen was significant only on $S_{15}(p<0.01)$. For $S_{4}$, no multiple regression was significant $(p>0.10)$. 
Table 5. Comparison of treatment means and standard deviations (in parentheses) of measured indicator values with linear transformed scores used for PCA and correlation analysis-chosen minimum data set (MDS) variables.

\begin{tabular}{lllll}
\hline & Bulk density & Total nitrogen & Urease & Available phosphorus \\
\hline$S$ & $0.79(0.01)$ & $0.72(0.10)$ & $0.65(0.2)$ & $0.68(0.10)$ \\
$S_{0}$ & $0.87(0.05)$ & $0.28(0.08)$ & $0.43(0.1)$ & $0.78(0.08)$ \\
$S_{1}$ & $0.87(0.02)$ & $0.32(0.04)$ & $0.56(0.1)$ & $0.68(0.01)$ \\
$S_{4}$ & $0.91(0.03)$ & $0.39(0.06)$ & $0.53(0.1)$ & $0.81(0.01)$ \\
$S_{10}$ & $0.95(0.03)$ & $0.51(0.06)$ & $0.46(0.1)$ & $0.70(0.10)$ \\
$S_{15}$ & $0.86(0.04)$ & $0.38(0.08)$ & $0.66(0.1)$ & $0.83(0.03)$ \\
\hline
\end{tabular}

$S$ : undisturbed soils; $S_{0}$ : recently mined; $S_{1}: 1$ year old mined; $S_{4}: 4$ year old mined; $S_{10}: 10$ year old mined; $S_{15}: 15$ year old mined.

The linear score for the bulk density did not appear to be justifiable environmentally, due to the exploitation of pumice left uncovered. Deeper horizons and the value of the density showed an increase; for this reason, this value was eliminated in the additive index. The high variability for $\mathrm{TN}$, from

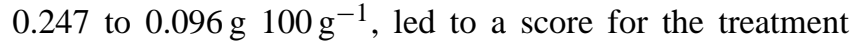
means ranging from 0.72 to 0.28 , a range that was probably too broad (Table 5). Figure 1 shows the relative indicator scores (the sum of the linear score obtained in Table 5 for each variable); for the MDS scoring combinations of the additive index, $S$ received significantly higher SQI value and did not show significance differences with $S_{4}, S_{10}$ and $S_{15}$, whereas the soil with less time of extraction $\left(S_{0}\right.$ and $\left.S_{1}\right)$ presented the lower values of SQI and was significantly different $(p<0.05)$ (Fig. 1).

\section{Discussion}

The loss of SOC and TN observed in soils post-pumice mining is typical of major ecosystem disturbance (Kimble et al., 2001). In these soils a loss of up to $60 \%$ is observed. These results are similar to the study by de Souza et al. (2013) and Zhang et al. (2015) in forest soils. The quantity of organic matter $(\mathrm{C}$ and $\mathrm{N})$ and rates of microbial $\mathrm{C}$ mineralization to $\mathrm{CO}_{2}$ (respiration) were recovered with age in mining soil. The depletion of SOC produces a decline in soil quality associated with the reduction of available water capacity; about $15 \%$ is lost in soil post-pumice, nutrient concentration and soil structure (Schwenke et al., 2000).

The recovery of MBC in these soils was faster than SOC. This may indicate that the proportion of bio-available $\mathrm{C}$ in 15 year old soils has become similar to that of undisturbed soils, but may also be the result of an increased availability of TN (evidenced by lower $\mathrm{C} / \mathrm{N}$ ratios in older soils) and available $\mathrm{P}$ (as a result of fertilization). The MBC that was greatly reduced from the undisturbed soil in the mine soil was estimated to be an average of $46 \%$ (Zhang et al., 2015). This result indicated that the land degradation is associated with a strong decrease in the SOC content, which decreased to $58 \%$ in recently mine soils with respect to undisturbed soil.

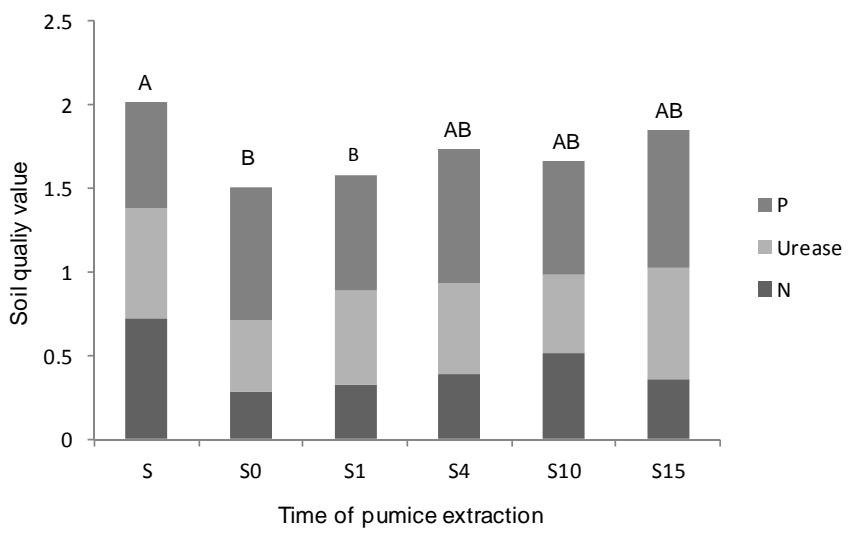

Figure 1. Additive soil quality index using linear scoring indicators chosen by principal component analysis and correlation analysis minimum data set (MDS) variables.

The soil basal respiration and $q \mathrm{CO}_{2}$ in mine soil showed no significant differences $(p>0.05)$; it can be explained by an increase in the contents of SOC and nutrients, which would enhance microbial activity (Emmerling et al., 2000; Yan et al., 2003), and biomass cycling (Yang et al., 2012).

This establishes, as the MBC becomes more efficient in using the available resources, that less $\mathrm{C}$ is lost as $\mathrm{CO}_{2}$ through respiration (García-Orenes et al., 2010). Soil microbial quotients in several ecosystems have been found to increase immediately post-disturbance and subsequently decline with age (Insam and Domsch, 1988; Schipper et al., 2001; Graham and Haynes, 2004). This pattern of microbial quotient has been interpreted as indicative of a decrease in $\mathrm{C}$ bioavailability in the soil organic matter over time. The microbial quotient of 0 year old was higher than other mine soils, and it tended to increase with age. The respiration rate per unit of microbial biomass (respiratory quotient) is a variable that can be interpreted more easily (Fernandes et al., 2005).

In this study, urease in soil samples with recent extraction of pumice was significantly lower than in soil control. This enzyme activity increased with increasing time of pumice extraction. Other studies found higher values in MBC and urease activity in the abandoned agricultural soils (Zornoza 
et al., 2009) and included MBC and MBN and enzymatic activities, probably due to high sensitivity (Zornoza et al., 2015). According to PCA and multiple regressions, urease, available phosphorus and bulk density are the three most important variables for the soil quality assessment. Among the different enzymes in soils, urease is important in the transformation of urea to ammonium.

The mining activity in the study site has affected bulk density significantly, and therefore the root response of the cultivated plants after the extraction could be affected. Previous research suggested bulk density as a soil quality indicator because this measurement is generally responsive to management practices and is primarily a measure of soil compaction (Hussain et al., 1999). The soil under recent time, 1 and 4 years of pumice extraction, did not show significant differences, whereas $S_{10}$ and $S_{15}$ presented significantly higher values; this behavior is attributed to agricultural land management, such that the continuous addition of organic matter to the soil increases the availability of phosphorus.

For linear scores, some cases showed high variability in the range observed, for example the variability in TN; nevertheless, urease, phosphatase and TN were considerable for the additive SQI. With the SQI, significant differences were observed between different years of exploitation of pumice $(p<0.05), S_{15}, S_{10}$ and $S_{4}$ showed behavior more similar to $\mathrm{S}$, and the time of recuperation is likely to start at 4 years, while $S_{0}$ and $S_{1}$ were the most different with respect to $S$.

\section{Conclusions}

This study showed that pumice extraction has had an adverse impact on the quality of soils cultivated with maize. What is most evident in the first years after the mine: after several cycles of cultivation MBC, urease and phosphate activities increased as a result of the continuous addition of organic matter.

Using multivariate analysis provided information about soil indicators that contributed to a greater extent to determine the effects of extraction pumice.

Among the evaluated quality indicators, urease and available phosphorus provided information to diagnose the quality of the soil where pumice was removed.

According to SQI, the time of recuperation of the soil under pumice mining starts 4 years after its exploitation.

Edited by: P. Pereira

\section{References}

Alef, K. and Nannipieri, P.: Enzyme activities: urease activity, in: Methods in Applied Soil Microbiology and Biochemistry, edited by; Alef, K. and Nannipieri, P., London, Academic Press, 311373, 1995.
Anderson, T. H. and Domsch, K. H.: Application of ecophysiological quotients $\left(q \mathrm{CO}_{2}\right.$ and $\left.q \mathrm{D}\right)$ on microbial biomass from soils of different crop histories, Soil Biol. Biochem., 22, 251-255, 1990.

Andrew, S. S., Karlen, D. L., and Mitchell, J. P.: A comparison of soil quality indexing methods for vegetable production systems in Northern California, Agric. Ecosys. Environ., 90, 25-45, 2002.

Bai, X. Y., Wang, S. J., and Xiong, K. N.: Assessing spatialtemporal evolution processes of karst rocky desertification land: indications for restoration strategies, Land Degrad. Dev., 24, 4756, 2013.

Berendse, F., van Ruijven, J., Jongejans, E., and Kreestra, S.: Loss of plant species diversity reduces soil reduces resistence, Ecosys, 18, 881-888, 2015.

Brevik, E. C., Cerdá A., Mataix-Solera, J., Quinton, J. N., Six, J., and Van Oost, K.: The interdisciplinary nature of soil, Soil, 1, 117-129, doi:10.5194/soil-1-117-2015, 2015.

Bremner, J. M.: Nitrogen total, in: Method of Soil Analysis, Part 3 chemical Methods SSSA Inc, edited by: Spark, D. L., ASA INC, Madison, WI, USA, 575-624, 1996.

Caldwell, B. A.: Enzyme activities as a component of soil biodiversity: A review, Pedobiologia, 49, 637-644, 2005.

Cerdà, A. and Lavee, H.: The effect of grazing on soil and water losses under arid and mediterranean climates, Implications for desertification, Pirineos, 153/154, 159-174, 1999.

Chodak, M. and Niklinska, M.: Effect of texture and tree species on microbial properties of mine soils, Appl. Soil Ecol., 46, 268-275, 2010.

De Souza, R. G., Da Silva, D. K. A., De Mello, C. M. A., Goto, B. T., Da Silva, F. S. B., Sampaio, E. V. S. B., and Maia, L. C.: Arbuscular mycorrizal fungi in vegetation mined dunes, Land, Degrad. Develop., 24, 147-153, 2013.

Domínguez, R. I. and Aguilera, N. H.: Metodología de Análisis Físicos y Químicos de Suelos, Facultad de Ciencias, UNAM, México, 1987.

Emmerling, C., Liebner, C., Haubold-Rosar, M., Katzur, J., and Schröder, D.: Impact of application of organic waste materials on microbial and enzyme activities of mine soils in the Lusatian coal mining region, Plant Soil, 220, 129-138, 2000.

Fernandes, S. A. P., Bettiol, W., and Cerri, C. C.: Effect of sewage sludge on microbial biomass, basal respiration, metabolic quotient and soil enzymatic activity, Appl. Soil Ecol., 30, 65-77, 2005.

Frouz, J., Keplin, B., Pižl, V., Tajovský, K., Starý, J., Lukešová, A., Nováková, A., Balıik, V., Háněl, L., Materna, J., Düker, C., Chalupský, J., Rusek, J., and Heinkele, T.: Soil biota and upper soil layer development in two contrasting post-mining chronosequences, Ecol. Eng., 17, 275-284, 2001.

García-Orenes, F., Guerrero, C., Roldán, A., Mataix-Solera, J., Cerda, A., Campoy, M., Zornoza, R., Bárcenas, G., and Caravaca, F.: Soil microbial biomass and activity under different agricultural management systems in a semiarid Mediterranean agroecosystem, Soil Till. Res., 109, 110-115, 2010.

Gianfreda, L., Rao, M. A., Piotrowska, A., Palumbo, G., and Colombo, C.: Soil enzyme activities as affected by anthropogenic alterations: intensive agricultural practices and organic pollution, Sci. Total Environ., 341, 2265-279, 2005.

GEM-ICEGEM: Estadística Básica Municipal del Estado de México, 2012. 
Graham, M. H. and Haynes, R. J.: Organic matter status and the size, activity and metabolic diversity of the soil microflora as indicators of the success of rehabilitation of sand dunes, Biol. Fert. Soils, 39, 429-437, 2004.

Guénon, R., Vennetier, M., Dupuy, N., Roussos, S., Pailler, A., and Gros, R.: Trends in recovery of Mediterranean soil chemical properties and microbial activities after infrequent and frequent wildfires, Land Degrad. Dev., 2, 115-128, 2013.

Haigh, M., Reed, H., Flege, A., D’acourt, M., Plamping, K., Cullis, M., Wooduffe, P., Sawyer, S., Panhuis, W., Wilding, G., Farrugia, F., and Powell, S.: Effect of planting method of the growth of Alnus glutinosa and Quercus petrea in compacted opencast coalmine spoils south Gales, Land Degrad. Dev., 26, 227-233, 2015.

Huggett, R. J.: Soil chronosequences, soil development, and soil evolution: a critical review, Catena, 32, 155-172, 1998.

Hussain, I., Olson, K. R., Wander, M. M., and Karlen, D. L.: Adaptation of soil quality indices and application to three tillage systems in southern Illinois, Soil Till. Res., 50, 237-249, 1999.

Hussain, M., Ahmed, S. M., and Abderrahman, W.: Cluster analysis and quality assessment of logged water at an irrigation project, eastern Saudi Arabia, J. Environ. Manage., 86, 297-307, 2008.

Insam, H. and Domsch, K. H.: Relationship between soil organic carbon and microbial biomass on chronosequences of reclamation sites, Microb. Ecol., 15, 177-188, 1988.

IUSS Working Group WRB. World Reference Base for Soil Resources 2014, International soil classification system for naming soils and creating legends for soil maps, World Soil Resources Reports No. 106. FAO, Rome, 2014.

Izzo, M., Araujo, N., Aucelli, P. P. C., Maratea, A., and Sánchez, A.: Land sensitivity to Desertification in the Dominican Republic: an adaptation of the ESA methodology, Land Degrad.Dev., 24, 486498, 2013.

Jiménez, C., Huante, P., and Rincón E.: Restauración de minas superficiales en México, SEMARNAT, Technical report, 2006.

Johnson, J. L. and Temple, K. L.: Some Variable Affecting the Measurement of Catalase Activity in Soil, Soil Sci. Soc. Am. J., 28, 207-209, 1964.

Keskin, K. and Makineci, E.: Some soil properties on coal mine spoils reclaimed with black locust (Robinia pseudoacacia L.) and umbrella pine (Pinuspinea L.) in Agacli-Istanbul, Environ. Monit. Assess., 159, 407-414, 2009.

Keesstra, S. D., Geissen, V., van Schaik, L., Mosse., K., and Piiranen, S.: Soil as a filter for groundwater quality, Curr. Opin. Environ. Sustainab., 4, 507-516, 2012.

Kimble, J. M., Lal, R., and Mausbach, M.: Erosion effects on soil organic carbon pool in soils of Iowa, in: Sustaining the Global Farm edited by: Stott, D. E., Mohtar, R. H., and Steinhardt, G. C., Washington, USDA-ARS, 190-224, 2001.

Kröpfl, A. I., Cecchi, G. A., Villasuso, N. M., and Distel, R. A.: Degradation and recovery processes in Semi-Arid patchy rangelands of northern Patagonia, Argentina, Land Degrad. Dev., 24, 393-399, 2013.

Laudicina, V. A., Novara, A., Barbera V., Egli, M., and Badalucco, L.: Long term and cropping system effects on chemical and biochemical characteristics of soil organic matter in a Mediterranean semiarid environment, Land Degrad. Dev., 26, 45-53, 2015.

Li, X. L., Gao, J., Brierley, G., Qiao, Y. M., Zhang, J., and Yang, Y. W.: Rangeland degradation on the Qinghai-Tibet plateau: Implications for Rehabilitation, Land Degrad. Dev., 24, 72-80, 2013.
Liguori, V., Sciorta, R., and Ruisi, V.: The pumice aggregates of Lipari Island (Aeolian Isles-Italy), Bull. Int. Assoc. Eng. Geol., 30, 431-434, 1984.

Martín-Moreno, M. C., Martín, D. J .F., Nicolau, I. J. M., Hernando, R. N., Sanz, S. M. A., and Sánchez, C. L.: Effects of topography and surface soil cover on erosion for mining reclamation; The experimental spoil heap at el Machorro Mine (Central Spain), Article first published on line, 27 June 2013, doi:10.1002/ldr.2232, 2013.

Milder, A. I., Fernandez-Santos, B., and Martínez-Ruíz, C.: Colonization patterns of woody species on lands mined for coal in Spain: Preliminary insights for forest expansion, Land Degrad. Dev., 24, 39-46, 2013.

Mukhopadhyay, S., Maiti, S. K., and Masto, R. E.: Use of Reclaimed Mine Soil Index (RMSI) for screening of tree species for reclamation of coal mine degraded land, Ecol. Eng., 57, 133142, 2013.

Nannipieri, P., Grego, S., and Ceccanti, B.: Ecological significance of the biological activity in soil, in: Soil Biochemistry, edited by: Bollag, J. M. and Stotzky, G., New York, Marcel Dekker, 293355, 1990.

Nelson, D. W. and Sommers, L. E.: Total carbon, organic carbon, and organic matter, in: Methods of Soil Analysis, Part III. Chemical Methods, edited by: Sparks, D. L. Madison, WI, American Society of Agronomy, 961-1010, 1996.

Oldeman, L. R.: Guidelines for general assessment of the status of human-induced soil degradation. Working paper 88/4, International Soil Reference and Information Centre (ISRIC), Wageningen, 1998.

Özcan, M., Gökbulak, F., and Hizal, A.: Exclosure effects on recovery of selected soil properties in a mixed brad leaf recreation site, Land Degrad Dev., 24, 266-276, 2013.

Pallavicini, Y., Alday, J. G., and Martínez-Ruíz, C.: Factors affecting herbaceous richness and biomass accumulation patterns of reclaimed coal mines, Land Degrad. Dev.,26, 211-217, 2015.

Raizada, A. and Juyal, G. P.: Tree species diversity, species regeneration and biological productivity of seeded Acacia catechu Willd in rehabilitated limestone mines in the north west Indian Himalayas, Land Degrad. Dev., 23, 167-174, 2012.

Rogowski, A. S. and Weinrich, B. E.: Modeling the effects of mining and erosion on biomass production, Ecol. Model., 35, 85-12, 1987.

Schipper, L. A., Degens, B. P., Sparling, G. P., and Duncan, L. C.: Changes in microbial heterotrophic diversity along five plant successional sequences, Soil Biol. Biochem., 33, 2093-2103, 2001.

Schwenke, G. D., Ayre, L., Mulligan, D. R., and Bell, L. C.: Soil stripping and replacement for the rehabilitation of bauxite-mined land at Weipa, II. Soil organic matter dynamics in mine soil chronosequences, Aust. J. Soil Res., 38, 371-394, 2000.

Shaw, E. J. and Burns, R. G.: Enzyme activities profiles and soil quality, in: Microbiological Methods for Assessing Soil Quality, edited by: Bloem, J., Hopkins, D. W., and Benedetti, A., Wallingford, CAB International, 158-171, 2006.

Sinsabaugh, R. L., Reynolds, H., and Long, M.: Rapid assay for amidohydrolase (urease) activity in environmental samples, Soil Biol. Biochem., 32, 2095-2097, 2000.

Sourkova, M., Frouz, J., and Fettweis, U.: Soil development and properties of microbial biomass succession in reclaimed post- 
mining sites near Sokolov (Czech Republic) and near Cottbus (Germany), Geoderma, 129, 73-80, 2005.

Tabatabai, M. A. and Bremner, J. M.: Use of r-nitrophenyl phosphate for assay of soil phosphatase activity, Soil Biol. Biochem., 1, 301-307, 1969.

Tabatabai, M. A. and Dick, W. A.: Enzymes in soil, in: Enzymes in the Environment: Activity, Ecology and Applications, edited by: Burns, R. G. and Dick, R. P., New York, Marcel, 567-596, 2002.

Tejada, M. and Benítez, C.: Effects of crushed maize Straw residues on soil biological properties and soil restoration, Land Degrad. Dev., 25, 501-509, 2014.

Thomas, G. W.: Soil pH and soil acidity, in: Methods of Soil Analysis Part 3, Chemical Methods, edited by: Sparks, D. L., Madison, Wisconsin, American Society of Agronomy, 475-490, 1996.

Vance, E. D., Brookes, P. C., and Jenkinson, D. S.: An Extraction Method for Measuring Soil Microbial Biomass C, Soil Biol. Biochem., 19, 703-707, 1987.

Wang, B., Xue, S., Liu, G. B., Zhang, G. H., Li, G., and Ren, Z. P.: Changes in soil nutrient and enzyme activities under different vegetations in the Loess Plateau area, Northwest China, Catena, 92, 186-195, 2012.

Wang, T., Yan, C. Z., Song, X., and Li, S.: Landsat images reveal trends in the aeolian desertification in a source area for sand and dust storms in China's Alashan plateau (1975-2007), Land Degrad. Dev., 24, 422-429, 2013.

Wick, A. F., Daniels, L. W., Nash, W. L., and Burger, J. A.: Aggregate recovery in reclaimed coal mine soils of SW Virginia, Land Degrad. Dev., doi:10.1002/ldr.2309, 2014.

Whitham, A. G. and Sparks, R. S. J.: Bull. Volcanol., 48, 209-223, 1986.
Yan, X. and Cai, Y. L.: Multi-Scale Anthropogenic Driving Forces of Karst Rocky Desertification in Southwest China, Land Degrad. Dev., 26, 193-200, 2015.

Yan, T. M., Yang, L. Z., and Campbell, C. D.: Microbial biomass and metabolic quotient of soils under different land use in the Three Gorges Reservoir area, Geoderma, 115, 129-138, 2003.

Yang, D., Zeng, D.-H., Zhang, J. L., Li, L.-J., and Mao, R.,: Chemical and microbial properties in contaminated soils around a magnesite mine in northeast China, Land Degrad. Dev., 24, 256-262, 2012.

Zhang, K., Zheng, H., Chen, F. L., Ouyang, Z. Y., Wang, Y., Wu, Y. F., Lan, J., Fu, M., and Xiang, X. W.: Changes in soil quality after converting Pinus to Eucalyptus plantations in southern China, Solid Earth, 6, 115-123, doi:10.5194/se-6-115-2015, 2015.

Zornoza, R., Mataix-SDoera, J., Guerrero, C. V., Arcenegui, V., and Mataix-Beneyto, J.: Comparison of Soil Physical, Chemical, and Biochemical Properties Among Native Forest, Maintained and Abandoned Almond Orchards in Mountainous Areas of Eastern Spain, Arid. Land Res. Manag., 23, 267-282, 2009.

Zornoza, R., Acosta, J. A., Bastida, F., Dominguez, S. G., Toledo, D. M., and Faz, A.: Identification of sensitive indicators to assess the interrelationship between soil quality, management practices and human health, Soil, 1, 173-185, doi:10-5194/soil-1-173-2015, 2015.

Zucca, C., Wu, W., Dessena, L., and Mulas, M.: Assessing the effectiveness of land restoration interventions in dry lands by multitemporal remote sensing-a case study in ouleddlim (Marrakesh, Morocco), Land Degrad. Dev., 26, 80-91, 2015. 